University of Michigan Law School

University of Michigan Law School Scholarship Repository

\title{
Reply to Richard A. Leo and Jon B. Gould
}

\author{
Samuel R. Gross \\ University of Michigan Law School, srgross@umich.edu \\ Barbara O'Brien \\ Michigan State University College of Law
}

Available at: https://repository.law.umich.edu/articles/1588

Follow this and additional works at: https://repository.law.umich.edu/articles

Part of the Courts Commons, Criminal Law Commons, and the Law Enforcement and Corrections Commons

\section{Recommended Citation}

Gross, Samuel R. "Reply to Richard A. Leo and Jon B. Gould." B. O'Brien, co-author. Ohio St. J. Crim. L. 8, no. 2 (2010): 273-6.

This Article is brought to you for free and open access by the Faculty Scholarship at University of Michigan Law School Scholarship Repository. It has been accepted for inclusion in Articles by an authorized administrator of University of Michigan Law School Scholarship Repository. For more information, please contact mlaw.repository@umich.edu. 


\section{Letters to the Journal}

The following is a letter to the Ohio State Journal of Criminal Law received from Professors Samuel Gross and Barbara O'Brien, responding to an article published in the Journal in Fall 2009 by Professors Richard Leo and Jon Gould. This letter is followed by a reply from Professors Leo and Gould. Professors Gross and O'Brien did not see the reply prior to the Journal going to press.

As we have indicated before, we welcome letters to the Journal from readers on any topic covered in a prior issue. - Editors

\section{Dear Journal:}

In a recent article in your pages, Studying Wrongful Convictions: Learning from Social Science, ${ }^{1}$ Professors Richard Leo and Jon Gould criticize our work. We think a few words of clarification might be useful.

1. One of Leo and Gould's repeated criticisms ${ }^{2}$ is that in a joint article that we published in $2008,{ }^{3}$ and a separate piece by one of us that appeared the same year, ${ }^{4}$ we failed to cite several published studies by criminologists. This is true. Some of these studies were omitted because we did not believe that their conclusions were reliable. Other omissions were oversights, which we regret.

2. We disagree with many of the methodological assertions in Leo and Gould's article, but we will mention only one that bears directly on our own work. Leo and Gould criticize us for using chi-square tests on cross tabulations that present data on predictors of false convictions: "Indeed, the association is even less predictive when researchers use, as Gross and O'Brien have, a chi-square test of correlation, rather than seeking to conduct a regression [analysis] that offers more informative inferential statistics.",

Strictly speaking, a chi-square statistic is a test of the null hypothesis of independence. Rejection of that hypothesis implies a correlation between the variables involved, but the test provides no measure of that correlation. Instead, the interpretation of such cross tables-which are almost as common in social scientific studies as footnotes in law review articles-depends on a direct

I Richard A. Leo \& Jon B. Gould, Studying Wrongful Convictions: Learning from Social Science, 7 OHo ST. J. CrIM. L. 7 (2009).

2 Id. at 10 n.26, 24 n.94.

3 Samuel R. Gross \& Barbara O'Brien, Frequency and Predictors of False Conviction: Why We Know So Little, and New Data on Capital Cases, 5 J. EMPIRICAL LEGAL STUD. 927 (2008).

4 Samuel R. Gross, Convicting the Innocent, 4 ANN. REV. L. \& SOC. ScI. 173 (2008).

5 Leo \& Gould, supra note 1, at 25. 
comparison of the numbers in the cells. Here, for example, is a simplified version of one table that we used: ${ }^{6}$

\section{Executions and Capital Exonerations in the United States 1973-2003, Confessions at Trial}

\begin{tabular}{l|c|c} 
& Executions & Exonerations \\
\hline $\begin{array}{l}\text { Defendant } \\
\text { Confessed }\end{array}$ & $\mathbf{5 2 \%}(\mathbf{6 9 / 1 3 3 )}$ & $\mathbf{1 5 \% ( 1 6 / 1 0 5 )}$ \\
\hline \multicolumn{2}{l}{$\chi^{2}(1, N=238)=34.31, p<.001$}
\end{tabular}

The chi-square test is displayed on the bottom line: $\chi^{2}(1, N=238)=34.31, p$ $<.001$. It means that there is less than one chance in one thousand that a difference as large as this, or larger, would occur by chance alone if in fact confessions were equally likely in cases of capital defendants who were executed and in cases of capital defendants who were exonerated. That's all it means. Beyond that, the numbers speak for themselves.

Regression analysis, especially multiple regression analysis, is more complex and does provide more elaborate statistics. But is it more informative? That's a different question. No statistical technique is better than another or "more predictive" in the abstract. Whether regression analysis, or any technique, is best depends on the question one is investigating and the data that are available to do so. In this case the available data are limited and highly imperfect. We are familiar with regression analysis. We have used regression analyses in published and unpublished work. We did not use regression analysis in this study because we concluded that direct comparison of frequencies, with tests of independence, was the best method for addressing the questions at hand.

3. Leo and Gould's central criticism focuses on our general outlook. We wrote: "Our main message is gloomy. We do not know much about false convictions, and it will be difficult to learn more." They disagree. Other researchers we have talked to are also more optimistic than us; none, to our knowledge, is more cautious. We would have been happy to chalk up this difference to a disparity in temperament: Leo and Gould see the glass as half full;

6 Gross \& O'Brien, supra note 3, at 953 tbl.4. The original table also included a second comparison between executions and capital exonerations: whether the defendant made no claim of innocence at trial.

7 Id. at 958 . 
we see it as rather more than half empty. But they insist on this point; they write that their disagreement with our pessimism "is not merely an academic matter."

Since Leo and Gould take us to task, they should perhaps have mentioned the reasons we give for our gloomy outlook. The articles we wrote are in large part discussions of the methodological difficulties of studying false convictions. We will not repeat what they say - the originals are available to anyone who might be interested-but will mention two of the major issues we explore:

There are no decent case-level data on accurate criminal convictions in the United States, or on all criminal convictions, with which to compare data on exonerations. ${ }^{9}$ This is a huge handicap to any effort to make causal inferences about false convictions, regardless of the method of statistical analysis one uses. ${ }^{10}$

Ninety-five percent of known false convictions-exonerations-occur in cases of murder or rape, the two most serious common crimes of violence, which, between them, account for only about two percent of felony convictions. " That means that we know very little about false convictions for any other crimes of violence and virtually nothing about false convictions for non-violent felonies and misdemeanors. (And even among rape cases, the false convictions we know about are concentrated among the minority of defendants who receive very long prison sentences. ${ }^{12}$ )

Ultimately, the most important facet of Leo and Gould's discussion of our work is probably the dog that didn't bark: Despite some pointed criticism, they never actually disagree with any of our conclusions or findings (unless somehow we missed it), only with our glum attitude. In fact, most of the major findings about false convictions that they discuss are ones that we too reported.

$8 \quad$ Leo \& Gould, supra note 1, at 29.

9 Gross \& O’Brien, supra note 3, at 937-40. See generally id. at 929-35.

10 Leo and Gould advocate "matched comparison" as a basis for causal inference. Apparently Leo and Gould define "matched comparison" widely, since they apply the term (which we never use) to our own joint study. Leo \& Gould, supra note 1, at 23. We do discuss a class of methods which includes this one: comparisons between groups of cases that are assembled by reference to their outcomes-in this context, comparisons between known false convictions (exonerations) and cases that are known or assumed to be "true convictions." Gross \& O'Brien, supra note 3, at 948. As we point out, almost all generalizations about false convictions are based on this type of comparisonsometimes explicit, sometimes implicit. But it is a comparatively weak basis for inference, and it certainly does not overcome the absence of data. No analytic technique is a substitute for reliable data, any more than a good paint job is a substitute for a solid foundation. (Professor Brandon Garrett did use a traditional "matched comparison group" (his term) to examine the treatment of false convictions on appellate review; see Brandon L. Garrett, Judging Innocence, 108 COLUM. L. REV. 55, 94 (2008), a study which Leo and Gould discuss. Leo \& Gould, supra note 1, at 22-23. But Garrett was studying differences between two sets of written opinions on appeal, a category of criminal justice decisions for which we have uncommonly good records. In that context, this is a useful technique.)

11 Gross \& O'Brien, supra note 3, at 938; Gross, supra note 4, at 179. See generally id. at 179-86.

12 See Gross, supra note 4, at 180. 
We agree entirely with Leo and Gould that "[w]rongful convictions cry out for reform and prevention,"13 and we agree with their general premise that high quality empirical research is critical to any effort to attack this tragic problem. We hope and trust that they will continue to add to that body of knowledge.

Samuel R. Gross*

Barbara O'Brien"

13 Leo \& Gould, supra note 1, at 29.

- Thomas and Mabel Long Professor of Law, University of Michigan Law School.

** Assistant Professor of Law, Michigan State University College of Law. 